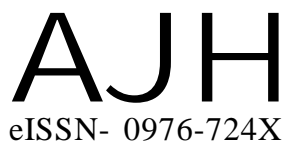

Received : 02.12.2015

Revised : 05.04.2016

Accepted : 19.04.2016

Members of the Research Forum

Associated Authors:

${ }^{1}$ All India Network Research Project on Onion and Garlic (AINRPOG),

Department of Horticulture,

Jawaharlal Nehru Krishi Vishwa

Vidyalaya, JABALPUR (M.P.) INDIA

Author for correspondence :

O.S. RAGHUWANSHI

All India Network Research Project

on Onion and Garlic (AINRPOG),

Department of Horticulture,

Jawaharlal Nehru Krishi Vishwa

Vidyalaya, JABALPUR (M.P.) INDIA

Email : omiraghu@gmail.com
THEASIAN JOURNAL OF HORTICULTURE

Volume 11 | Issue 1 | June, 2016 | 19-24

Visit us -www.researchjournal.co.in

\title{
Correlation and path analysis study in diverse onion (Allium cepa L.) genotypes
}

O.S. RAGHUWANSHI, P.K. JAIN ${ }^{1}$, S.K. SENGUPTA ${ }^{1}$, A.S. DANGI ${ }^{1}$, N.R. VERMA $^{1}$ AND SUNIL PRAJAPATI ${ }^{1}$

ABSTRACT : The association study resulted that the advantages of upgrading onion genotypes through simultaneous selection for equatorial diameter, followed by polar diameter, number of leaves plant ${ }^{-1}$ at 90 DAT, neck thickness, plant height at 90 DAT and TSS. Path coefficient analysis revealed that polar diameter had highest positive direct effect followed by plant height at 60 DAT, TSS, plant height at 90 DAT, number of leaves plant ${ }^{-1}$ at 90 DAT and polar: equatorial diameter were the most important traits contributing towards bulb yield plant ${ }^{-}$ ${ }^{1}$. Direct selection of equatorial diameter, neck thickness, days to maturity, number of leaves plant $^{-1}$ at 30 and 60 DAT and plant height at 30 DAT should be avoided instead of indirect selection. The highest production was observed in genotype OSR-1344 and Agrifound Light Red. Low incidence percentage of Stemphylium blight was found in genotype ON14-06 incidence percentage of thrips was found in genotype ON14-15. Considerable variability was observed among the genotypes for foliage character, bulb shape, bulb colour and bolting tendency. Foliage colour in green onion and shape and colour of onion bulb are most important characteristics to help customers in choosing cultivars in the market.

KEY WORDS : Onion, Character association, Path analysis, Yield

HOW TO CITE THIS ARTICLE : Raghuwanshi, O.S., Jain, P.K., Sengupta, S.K., Dangi, A.S., Verma, N.R. and Prajapati, Sunil (2016). Correlation and path analysis study in diverse onion (Allium cepa L.) genotypes. Asian J. Hort., 11(1) : 19-24, DOI : 10.15740/HAS/TAJH/11.1/19-24. 